\title{
Tidal and turbidity effects on the shallow-water fish assemblage of Kuwait Bay
}

\author{
Fadwa Abou-Seedo, David A. Clayton, John M. Wright
}

Zoology Department, Kuwait University, PO Box 5969, Safat 13060, Kuwait

\begin{abstract}
Effects of location, diel period, tidal condition and water clarity on the size and distribution of the shallow water fish assemblage of the non-estuarine Kuwait Bay, were investigated using a beach seine and a small research trawl during spring and summer 1989. Total numbers, biomass and numbers of species differed markedly between Doha, a sandy shore environment, and Kazmah, an extensive intertidal mud flat. When fish were present in large numbers there was a marked diel effect at both locations with many more fish captured during the night. Tidal effects were influenced by turbidity and the age structure of the assemblage. In clear water during spring, very young Liza carinata from the seine catches formed shoals at the edge of the rising tide both day and night, while fish 2 mo older formed shoals only on daytime rising tides. At Kazmah during spring, high turbidity obscured any tidal effects in the seine catches. In slightly deeper water, sampled by trawl during spring, Leiognathus decorus showed an asymmetrical tidal migration. In summer, beach seine catches were much higher on the rising tide. Summer trawl catches did not show a consistent tidal effect.
\end{abstract}

\section{INTRODUCTION}

Shallow non-estuarine environments have been shown to be important nursery areas for many species of fishes (Blaber \& Blaber 1980, Lenanton 1982, Ross et al. 1987). The extensive intertidal mud flats of Kuwait Bay have a tidal range of 3.5 to $4.0 \mathrm{~m}$ and are characterised by mixed semi-diurnal tides (Jones \& Clayton 1983). The fish assemblage of the intertidal and near-sublittoral of Sulaibikhat Bay $\left(29^{\circ} 21^{\prime} \mathrm{N}, 47^{\circ} 52^{\prime} \mathrm{E}\right)$, a semi-enclosed bay within Kuwait Bay, is dominated by juveniles of several species (Wright 1988a). This assemblage has been shown to fluctuate considerably between years (Wright 1989a), to have only 3 seasons in its annual cycle (Wright 1988b) and to show marked diel differences in the distribution of the assemblage (Wright 1989a).

The tidal migration of fishes in soft sediment habitats has been extensively studied in temperate environments (Gibson 1982), but has been largely ignored in subtropical and tropical environments (Quinn \& Kojis 1987). These onshore movements are considered to be due to several factors including feeding migrations, allowing the utilisation of intertidal productivity, and the avoidance of piscivores (Gibson 1982). Pleuronectes platessa Linnaeus has been found to make use of intertidal currents in its migrations (Jones et al. 1979, Walker et al. 1979). Relatively few intertidal migrant fish spawn on intertidal soft sediment environments. They may benefit from the avoidance of subtidal egg predators and possibly enhanced oxygen concentrations during low tide (Gibson 1982).

The influence of turbidity on the distribution of estuarine and inshore marine fish assemblages has been examined in Australia and South Africa (Blaber \& Blaber 1980, Cyrus \& Blaber $1987 \mathrm{a}, \mathrm{b})$. Turbid water may provide juveniles with cover from bird and fish predators and be beneficial due to the positive relationship between turbidity and benthic production (Cyrus \& Blaber 1987b).

This study was undertaken to assess the effect of tidal condition and water turbidity on the distribution and abundance of the shallow water fish assemblage of Kuwait Bay. Two sampling programmes were carried out. The first examined the effects of tidal condition, diel period and geographical location in spring and summer. The second sampling programme examined water clarity as well as tidal condition and diel period.

\section{MATERIALS AND METHODS}

The effect of location (L), diel period (D), tidal condition ( $\mathrm{T}$ ) and water clarity (C) on fish catches in shallow waters of Kuwait Bay were investigated using a beach 
seine and an otter trawl. The beach seine was $6.15 \mathrm{~m}$ long, $2.10 \mathrm{~m}$ high and constructed of $6.5 \mathrm{~mm}$ stretch mesh throughout. It was set in $0.5 \mathrm{~m}$ of water and hauled perpendicular to and toward the beach for $20 \mathrm{~m}$, sweeping an area of ca $120 \mathrm{~m}^{2}$. The otter trawl was of $4 \mathrm{~m}$ mouth width, made of $13 \mathrm{~mm}$ stretch mesh throughout, with a cod end of $6.5 \mathrm{~mm}$ stretch mesh. The net was trawled from a $7 \mathrm{~m}$ boat in a depth of 0.6 to $2.0 \mathrm{~m}$ at a speed of $0.5 \mathrm{~m} \mathrm{~s}^{-1}$ for $5 \mathrm{~min}$, sweeping an area of ca $600 \mathrm{~m}^{2}$.

Two sampling programmes were used. The first design examined $L, D$ and $T$, and was carried out at 2 locations, Doha and Kazmah (Fig. 1). Doha is a sandy shore while Kazmah is an extensive intertidal mudflat. Each sampling period at both locations consisted of 24 seine and 24 trawl hauls, with 12 hauls taken during daylight and 12 at night. Of these 12,6 were taken before and 6 after high water. The seine hauls were taken $1 \mathrm{~h}$ before and $1 \mathrm{~h}$ after high tide and trawls were taken $3 \mathrm{~h}$ before and $3 \mathrm{~h}$ after high tide. This programme was repeated, once in the spring between 6 and 9 March and once in the summer between 18 May and 3 June 1989. On both occasions trawls were taken at both locations during one $24 \mathrm{~h}$ period while the seines catches where taken over a period of $48 \mathrm{~h}$. Previous work has shown that the shallow water fish assemblage of the neighbouring Sulaibikhat Bay has a 3-season annual cycle corresponding to spring, summer and winter with very few fish present during the latter season (Wright 1988a, 1989a).

The second sampling programme was carried out at a third location in Sulaibikhat Bay, similar in character to Kazmah (Fig.1), to examine the effects of water clarity (C) as well as diel period (D) and tidal condition (T). Beach seines were taken, as in the first experimental design, on 2 occasions. The first was on 9 May, a calm day when the water was clear. Water was considered clear if the sediment surface was visible at the point where the seine haul was begun. Sampling was repeated under rough conditions on 31 May when the sediment surface was not visible in the shallowest water at the edge of the tide. Previous work at this location during spring has shown that there were no temporal effects in the assemblage over $18 \mathrm{~d}$ (Wright 1989b).

The total number of fishes $(\mathrm{N})$, total biomass (wet weight, B) and numbers of species were recorded for each haul. Total number and biomass data were transformed using $\log (x+1)$. When the variance and means were examined graphically it was found that the total numbers data for the spring seines consisted of separate Doha and Kazmah groups. These data were subsequently subjected to 2 -way analyses of variance (ANOVA) examining the effect of $T$ and $D$ and the remaining data were subjected to 3-way ANOVA's examining the effects of either $\mathrm{L}, \mathrm{D}$ and $\mathrm{T}$ or $\mathrm{C}, \mathrm{D}$ and $\mathrm{T}$ using the Generalised Linear Interactive Modeling program (GLIM: Baker \& Nelder 1978). Where appropriate, $t$-tests were used to determine which means were significantly different.

\section{RESULTS}

A total of 6809 fish belonging to 37 species in 22 families were captured during the entire sampling programme (Tables 1 to 5). Almost all of these fish were young of the year as expected from previous work (Wright 1988a).

\section{Fírst sampling programme}

\section{Spring trawl catches}

The spring trawl catches were small with numbers per trawl ranging between 0 and 12 at Doha and between 0 and 31 at Kazmah. Of the 48 trawls taken in

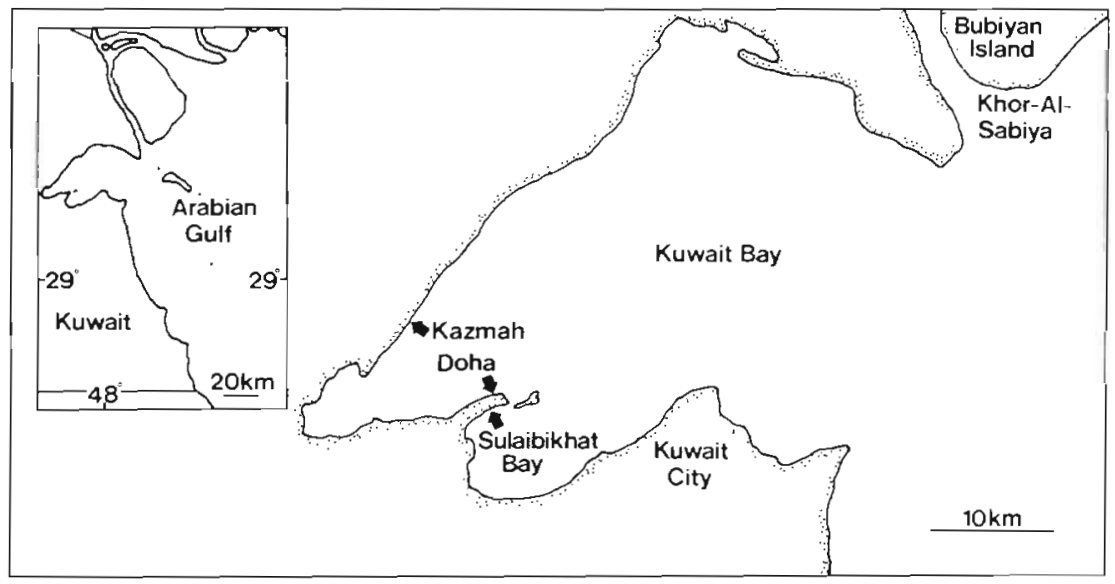

Fig. 1. Kuwait, showing location of sampling sites 
Table 1. Spring trawl catches at Doha and Kazmah. R: rising tide; F: falling tide

\begin{tabular}{|c|c|c|c|c|c|c|c|c|}
\hline \multirow[t]{3}{*}{ Family/Species } & \multicolumn{4}{|c|}{ Doha } & \multicolumn{4}{|c|}{ Kazmah } \\
\hline & \multicolumn{2}{|c|}{ Night } & \multicolumn{2}{|c|}{ Day } & \multicolumn{2}{|c|}{ Night } & \multicolumn{2}{|c|}{ Day } \\
\hline & $\mathrm{R}$ & $\mathrm{F}$ & $\mathrm{R}$ & $F$ & $\mathrm{R}$ & F & $\mathrm{R}$ & $\mathrm{F}$ \\
\hline \multicolumn{9}{|l|}{ Leiognathidae } \\
\hline Leiognathus decorus (de Vis) & 0 & 0 & 0 & 0 & 1 & 63 & 46 & 14 \\
\hline \multicolumn{9}{|l|}{ Sparidae } \\
\hline Diplodus sargus kotschyi (Steindachner) & 8 & 4 & 11 & 5 & 0 & 0 & 0 & 0 \\
\hline \multicolumn{9}{|l|}{ Mugilidae } \\
\hline Liza carinata (Valenciennes) & 0 & 0 & 0 & 0 & 2 & 0 & 0 & 0 \\
\hline \multicolumn{9}{|l|}{ Haemulidae } \\
\hline Pomadasys stridens (Forsskål) & 0 & 0 & 0 & 9 & 0 & 0 & 0 & 0 \\
\hline \multicolumn{9}{|l|}{ Engraulidae } \\
\hline Thryssa hamiltonii (Gray) & 0 & 0 & 0 & 0 & 0 & 0 & 0 & 1 \\
\hline \multicolumn{9}{|l|}{ Soleidae } \\
\hline Solea elongata (Day) & 0 & 1 & 1 & 0 & 0 & 10 & 0 & 0 \\
\hline \multicolumn{9}{|l|}{ Clupeidae } \\
\hline Sardinella gibbosa (Bleeker) & 0 & 0 & 0 & 2 & 0 & 0 & 2 & 0 \\
\hline \multicolumn{9}{|l|}{ Scorpaenidae } \\
\hline Pseudosynanceia melanostigma (Day) & 0 & 0 & 0 & 0 & 4 & 2 & 0 & 0 \\
\hline \multicolumn{9}{|l|}{ Mugilidae } \\
\hline Liza subviridis (Valenciennes) & 0 & 1 & 0 & 0 & 0 & 7 & 0 & 2 \\
\hline \multicolumn{9}{|l|}{ Sillaginidae } \\
\hline Sillago sihama (Forsskål) & 0 & 0 & 0 & 0 & 0 & 4 & 1 & 0 \\
\hline \multicolumn{9}{|l|}{ Sillaginidae } \\
\hline Sillago sp. & 0 & 0 & 0 & 0 & 2 & 0 & 0 & 0 \\
\hline \multicolumn{9}{|l|}{ Gobiidae } \\
\hline Apocryptes madurenesis (Bleeker) & 0 & 0 & 0 & 0 & 1 & 0 & 2 & 1 \\
\hline \multicolumn{9}{|l|}{ Trichiuridae } \\
\hline Eupleurogrammus glossodon (Bleeker) & 0 & 0 & 0 & 0 & 0 & 0 & 0 & 1 \\
\hline \multicolumn{9}{|l|}{ Hemiramphidae } \\
\hline Hemiramphus marginatus (Forsskål) & 0 & 0 & 0 & 0 & 0 & 0 & 0 & 4 \\
\hline \multicolumn{9}{|l|}{ Apogonidae } \\
\hline Apogonichthys uninotatus (Smith \& Radcliffe) & 1 & 3 & 0 & 0 & 0 & 0 & 0 & 0 \\
\hline \multicolumn{9}{|l|}{ Gobidae } \\
\hline Bathygobius fuscus (Rüppell) & 5 & 8 & 0 & 0 & 0 & 0 & 0 & 0 \\
\hline
\end{tabular}

the spring, zero catches were taken in 5 trawls. Significantly greater total numbers $(\mathrm{N})$ of fish were captured of Kazmah than at Doha (Table 6, Fig. 2). There was a highly significant D-T interaction so that catches on rising and falling tides were not independent of diel period. At Kazmah during the night, catches were greater on the falling tide than the rising tide, whilst in the day catches were greater on the rising than on the falling tide. This interaction was examined by comparing the mean catches in the day and night for both rising and falling tides at each location by using Student's t-tests. At Doha there was no significant difference between catches on the rising tide compared to the falling tide during either night or day. There were no significant differences between the rising tides of the night and day nor between the falling tides of the night and day. At Kazmah greater numbers of fish were captured on the night-time falling tide than on the night-time rising tide $(\mathrm{p}<0.001)$. There was no significant difference between rising and falling tides during the day. The catch on the rising tide at night was much less than on the rising tide in the day $(p<0.05)$, and the falling tide catch at night was 4 times greater than on the falling tide in the day ( $p<0.001$ ).

Total biomass (B) in the spring trawls was greater at Kazmah than at Doha $(\mathrm{p}<0.001$ ) and at night than during daylight ( $p<0.05$ ) (Table 6). Catches on rising and falling tides were not significantly different.

\section{Spring seine catches}

Spring seine catches ranged in numbers from 0 to 103 at Doha and 7 to 45 at Kazmah with only one zero catch. Total numbers ( $N$ ) were analysed separately for each location using 2-way ANOVA's (Table 6, Fig.3). 
Table 2. Spring seine catches at Doha and Kazmah. R: rising tide; F: falling tide

\begin{tabular}{|c|c|c|c|c|c|c|c|c|}
\hline \multirow[t]{3}{*}{ Family/Species } & \multicolumn{4}{|c|}{ Doha } & \multicolumn{4}{|c|}{ Kazmah } \\
\hline & \multicolumn{2}{|c|}{ Night } & \multicolumn{2}{|c|}{ Day } & \multicolumn{2}{|c|}{ Night } & \multicolumn{2}{|c|}{ Day } \\
\hline & $\mathrm{R}$ & F & $\mathrm{R}$ & $\mathrm{F}$ & $R$ & F & $\mathrm{R}$ & F \\
\hline \multicolumn{9}{|l|}{ Mugilidae } \\
\hline Liza carinata (Valenciennes) & 259 & 164 & 331 & 18 & 99 & 119 & 84 & 115 \\
\hline \multicolumn{9}{|l|}{ Sillaginidae } \\
\hline Sillago sp. & 7 & 0 & 1 & 0 & 7 & 0 & 19 & 24 \\
\hline \multicolumn{9}{|l|}{ Haemulidae } \\
\hline Pomadasys stridens (Forsskål) & 0 & 0 & 8 & 0 & 0 & 0 & 0 & 0 \\
\hline \multicolumn{9}{|l|}{ Sillaginidae } \\
\hline Sillago sihama (Forrskål) & 0 & 0 & 0 & 0 & 0 & 2 & 0 & 0 \\
\hline \multicolumn{9}{|l|}{ Gobiidae } \\
\hline Apocryptes madurenesis (Bleeker) & 0 & 0 & 0 & 0 & 5 & 0 & 1 & 1 \\
\hline \multicolumn{9}{|l|}{ Gobiidae } \\
\hline Bathygobius fuscus (Rüppell) & 1 & 0 & 0 & 0 & 0 & 0 & 0 & 0 \\
\hline \multicolumn{9}{|l|}{ Cyprinodontidae } \\
\hline Aphanius dispar (Rüppell) & 0 & 0 & 1. & 0 & 0 & 0 & 0 & 0 \\
\hline
\end{tabular}

At Doha there was a significant D-T interaction which was investigated by comparing the mean catch on rising and falling tides during both night and day. At night catches on rising and falling tides did not differ but in the day much greater numbers were captured on the rising than on the falling tide $(p<0.001)$. The rising tides of the night and day did not differ but larger numbers were captured on the night-time falling tide than on the daytime falling tide $(p<0.01)$. At Kazmah there was no significant diel or tidal effect, and the catches were very similar in all 4 tidal states sampled.

For total biomass $(B)$ in the spring seines there were significant D-T and L-T interactions (Table 6). The D-T interaction indicates that the relative difference between rising and falling tides was dependent on diel period. The L-T interaction indicates that tidal effects were different at the 2 locations. To examine the D-T interaction, means for both day and night and for rising and falling tides from Doha and Kazmah combined were compared. For Doha and Kazmah combined, rising and falling tide biomass did not differ during the night but in daylight greater biomass was taken on rising than on falling tides $(p<0.001)$. There was no difference in biomass of the rising tide at night and the rising tide in daylight but greater biomass was taken on the falling tide at night than on the falling tide in the day $(p<0.05)$. Irrespective of diel period there was no difference between biomass on rising tides at Doha and Kazmah but much greater biomass was captured on falling tides at Kazmah compared to Doha ( $p<0.001$ ). At Doha biomass was much greater on the rising tide compared to the falling tide $(p<0.001)$ whilst at Kazmah there was no difference between the tides.

\section{Surmmer trawl catches}

The summer trawl catches ranged between 1 and 69 individuals at Doha and between 0 and 47 at Kazmah with only one haul in which no fish were captured. For total numbers $(\mathrm{N})$ in the summer trawls, Doha catches were significantly greater than Kazmah (Table 7. Fig. 4). There was a significant D-T interaction which was investigated by comparing night and day means for both rising and falling tides at each location. At Doha during the night larger numbers were captured on the rising than on the falling tide $(p<0.01)$ whilst in daylight larger catches were taken on the falling than on the rising tide $(p<0.01)$. More fish were captured on the rising tide at night compared to the day ( $p<0.001$ ) and more fish were captured on the falling tide of night compared to the day $(p<0.01)$. At Kazmah catches on rising and falling tides did not differ either at night or in the day. Many more fish were captured on the night rising tide than on the daylight rising tide $(p<0.001)$ and more fish were captured on the night falling tide than in the day $(p<0.001)$.

Total biomass (B) in the summer trawls was very significantly greater at night than in the day but there were not significant location or tidal effects (Table 7).

\section{Summer seine catches}

Summer seine catches ranged between-0 and 135 at Doha and between 5 and 428 at Kazmah with 2 hauls containing no fish. Summer seine total numbers $(\mathrm{N})$ show very clear trends with highly significant location, diel and tidal effects (Table 7. Fig. 5). Numbers were 
Table 3. Summer trawl catches at Doha and Kazmah. R: rising tide; F: falling tide

\begin{tabular}{|c|c|c|c|c|c|c|c|c|}
\hline \multirow[t]{3}{*}{ Family/Species } & \multicolumn{4}{|c|}{ Doha } & \multicolumn{4}{|c|}{ Kazmah } \\
\hline & \multicolumn{2}{|c|}{ Night } & \multicolumn{2}{|c|}{ Day } & \multicolumn{2}{|c|}{ Night } & \multicolumn{2}{|c|}{ Day } \\
\hline & $\mathrm{R}$ & $\mathrm{F}$ & $\mathrm{R}$ & $\mathrm{F}$ & $\mathrm{R}$ & F & $\mathrm{R}$ & $\mathrm{F}$ \\
\hline \multicolumn{9}{|l|}{ Engraulidae } \\
\hline Thryssa hamiltonii (Gray) & 10 & 0 & 0 & 0 & 113 & 66 & 0 & 0 \\
\hline \multicolumn{9}{|l|}{ Gobijdae } \\
\hline Ctenogobius criniger (Cuvier \& Valenciennes) & 94 & 11 & 0 & 0 & 0 & 1 & 0 & 0 \\
\hline \multicolumn{9}{|l|}{ Sparidae } \\
\hline Acanthopagrus latus (Houttuyn) & 46 & 17 & 14 & 25 & 0 & 0 & 0 & 0 \\
\hline \multicolumn{9}{|l|}{ Teraponidae } \\
\hline Terapon puta (Cuvier) & 42 & 19 & 1 & 11 & 24 & 13 & 0 & 7 \\
\hline \multicolumn{9}{|l|}{ Leiognathidae } \\
\hline Leiognathus decorus (de Vis) & 5 & 34 & 3 & 6 & 1 & 1 & 26 & 14 \\
\hline \multicolumn{9}{|l|}{ Mugilidae } \\
\hline Liza carinata (Valenciennes) & 0 & 0 & 0 & 0 & 0 & 1 & 1 & 0 \\
\hline \multicolumn{9}{|l|}{ Haemulidae } \\
\hline Pomadasys stridens (Forsskål) & 7 & 15 & 0 & 0 & 0 & 0 & 0 & 0 \\
\hline \multicolumn{9}{|l|}{ Soleidae } \\
\hline Solea elongata (Day) & 7 & 3 & 0 & 0 & 0 & 1 & 0 & 0 \\
\hline Clupeidae & & & & & & & & \\
\hline Nematolosa nasus (Bloch) & 0 & 0 & 0 & 0 & 0 & 1 & 1 & 0 \\
\hline Ariidae & & & & & & & & \\
\hline Arius tenuispinis (Day) & 0 & 0 & 0 & 0 & 18 & 7 & 0 & 1 \\
\hline Gobiidae & & & & & & & & \\
\hline Acentrogobius ornatus (Rüppell) & 0 & 0 & 0 & 0 & 1 & 0 & 0 & 0 \\
\hline Scorpaenidae & & & & & & & & \\
\hline Pseudosynanceia melanostigma (Day) & 7 & 5 & 0 & 1 & 0 & 0 & 0 & 1 \\
\hline Clupeidae & & & & & & & & \\
\hline Llisha melastoma (Schneider) & 15 & 1 & 0 & 0 & 1 & 1 & 0 & 0 \\
\hline Sillaginidae & & & & & & & & \\
\hline Sillago sihama (Forsskål) & 0 & 0 & 0 & 0 & 0 & 1 & 2 & 0 \\
\hline Sillaginidae & & & & & & & & \\
\hline Sillago sp. & 40 & 11 & 0 & 0 & 1 & 1 & 1 & 0 \\
\hline Triacanthidae & & & & & & & & \\
\hline Pseudotriacanthus strigilifer (Cantor) & 0 & 0 & 2 & 1 & 0 & 0 & 0 & 0 \\
\hline Sparidae & & & & & & & & \\
\hline Diplodus sargus kotschyi (Steindachner) & 6 & 5 & 4 & 4 & 0 & 0 & 0 & 0 \\
\hline Sparidae & & & & & & & & \\
\hline Acanthopagrus berda (Forsskål) & 18 & 2 & 2 & 3 & 1 & 1 & 0 & 0 \\
\hline Haemulidae & & & & & & & & \\
\hline Pomadasys argenteus (Forsskål) & 0 & 0 & 2 & 1 & 0 & 0 & 0 & 0 \\
\hline Apogonidae & & & & & & & & \\
\hline Apogonichthys uninotatus (Smith \& Radcliffe) & 0 & 4 & 0 & 0 & 0 & 0 & 0 & 0 \\
\hline Batrachoididae & & & & & & & & \\
\hline Batrachus grunniens (Linnaeus) & 1 & 0 & 0 & 1 & 0 & 0 & 0 & 0 \\
\hline Tetraodontidae & & & & & & & & \\
\hline Chelonodon patoca (Buchanan) & 0 & 0 & 0 & 0 & 1 & 0 & 1 & 0 \\
\hline Ariidae & & & & & & & & \\
\hline Arius tenuispinis (Day) & 0 & 0 & 0 & 0 & 18 & 7 & 0 & 1 \\
\hline Scianedae & & & & & & & & \\
\hline Otolithes ruber (Schneider) & 0 & 0 & 0 & 0 & 4 & 6 & 0 & 0 \\
\hline Gymnuridae & & & & & & & & \\
\hline Gymnura poecilura (Shaw) & 0 & 0 & 0 & 0 & 1 & 0 & 0 & 0 \\
\hline Sciaenidae & & & & & & & & \\
\hline Johnius belangeri (Cuvier) & 0 & 1 & 0 & 0 & 2 & 1 & 0 & 0 \\
\hline Clupeidae & & & & & & & & \\
\hline Sardinella gibbosa (Bleeker) & 4 & 2 & 0 & 0 & 1 & 0 & 0 & 0 \\
\hline Gerreidae & & & & & & & & \\
\hline Gerres oyena (Forsskål) & 1 & 3 & 0 & 1 & 0 & 0 & 0 & 0 \\
\hline
\end{tabular}


Table 4. Summer seine catches at Doha and Kazmah. R: rising tide; F: falling tide

\begin{tabular}{|c|c|c|c|c|c|c|c|c|}
\hline \multirow[t]{3}{*}{ Family/Species } & \multicolumn{4}{|c|}{ Doha } & \multicolumn{4}{|c|}{ Kazmah } \\
\hline & \multicolumn{2}{|c|}{ Night } & \multicolumn{2}{|c|}{ Day } & \multicolumn{2}{|c|}{ Night } & \multicolumn{2}{|c|}{ Day } \\
\hline & $\mathrm{R}$ & $\mathrm{F}$ & $\mathrm{R}$ & $\mathrm{F}$ & $\mathrm{R}$ & F & $\mathrm{R}$ & $\mathrm{F}$ \\
\hline \multicolumn{9}{|l|}{ Mugilidae } \\
\hline Liza carinata (Valenciennes) & 1 & 1 & 0 & 0 & 860 & 141 & 29 & 11 \\
\hline \multicolumn{9}{|l|}{ Muqilidae } \\
\hline Liza sp. & 6 & 2 & 6 & 1 & 312 & 161 & 35 & 33 \\
\hline \multicolumn{9}{|l|}{ Cyprinodontidae } \\
\hline Aphanius dispar (Rüppell) & 187 & 54 & 7 & 3 & 0 & 0 & 0 & 0 \\
\hline \multicolumn{9}{|l|}{ Scorpaenidae } \\
\hline Pseudosynanceia melanostigma (Day) & 1 & 0 & 0 & 0 & 0 & 0 & 0 & 0 \\
\hline \multicolumn{9}{|l|}{ Sillaginidae } \\
\hline Sillago sp. & 1 & 0 & 9 & 0 & 16 & 23 & 13 & 1 \\
\hline \multicolumn{9}{|l|}{ Haemulidae } \\
\hline Pomadasys argenteus (Forsskål) & 0 & 0 & 1 & 1 & 0 & 0 & 0 & 0 \\
\hline \multicolumn{9}{|l|}{ Sparidae } \\
\hline Acanthopagrus latus (Houttuyn) & 0 & 0 & 2 & 0 & 0 & 0 & 0 & 0 \\
\hline \multicolumn{9}{|l|}{ Hemiramphidae } \\
\hline Hemiramphus marginatus (Forsskål) & 26 & 2 & 1 & 1 & 0 & 0 & 0 & 0 \\
\hline \multicolumn{9}{|l|}{ Clupeidae } \\
\hline Clupeid sp. & 0 & 0 & 1 & 0 & 0 & 0 & 0 & 0 \\
\hline
\end{tabular}

Table 5. Seine catches at Sulaibikhat Bay. R: rising tide; F: falling tide

\begin{tabular}{|c|c|c|c|c|c|c|c|c|}
\hline \multirow[t]{3}{*}{ Family/Species } & \multicolumn{4}{|c|}{ Clear } & \multicolumn{4}{|c|}{ Turbid } \\
\hline & \multicolumn{2}{|c|}{ Night } & \multicolumn{2}{|c|}{ Day } & \multicolumn{2}{|c|}{ Night } & \multicolumn{2}{|c|}{ Day } \\
\hline & $\mathrm{R}$ & $\mathrm{F}$ & $R$ & F & $\mathrm{R}$ & F & $\mathrm{R}$ & $\mathrm{F}$ \\
\hline \multicolumn{9}{|l|}{ Mugilidae } \\
\hline Liza carinata (Valenciennes) & 200 & 122 & 1027 & 55 & 57 & 14. & 154 & 46 \\
\hline \multicolumn{9}{|l|}{ Mugilidae } \\
\hline Liza sp. & 15 & 8 & 27 & 65 & 294 & 77 & 77 & 90 \\
\hline \multicolumn{9}{|l|}{ Clupeidae } \\
\hline Nematolosa nasus (Bloch) & 2 & 0 & 0 & 11 & 0 & 0 & 0 & 0 \\
\hline \multicolumn{9}{|l|}{ Sillaginidae } \\
\hline Sillago sp. & 56 & 19 & 0 & 5 & 1 & 5 & 19 & 14 \\
\hline \multicolumn{9}{|l|}{ Gobiidae } \\
\hline Scartelaos viridis (Hamilton-Buchanan) & 0 & 0 & 0 & 0 & 1 & 0 & 0 & 0 \\
\hline \multicolumn{9}{|l|}{ Belonidae } \\
\hline Strongylura strongylura (Van Hasselt) & 1 & 0 & 0 & 2 & 0 & 0 & 0 & 0 \\
\hline \multicolumn{9}{|l|}{ Gobiidae } \\
\hline Periophthalmus koelruten (Palias) & 0 & 0 & 0 & 0 & 2 & 0 & 0 & 0 \\
\hline \multicolumn{9}{|l|}{ Tetraodontidae } \\
\hline Chelonodon patoca (Buchanan) & 0 & 0 & 0 & 0 & 5 & 0 & 0 & 0 \\
\hline \multicolumn{9}{|l|}{ Clupeidae } \\
\hline Clupeid sp. & 0 & 0 & 0 & 0 & 5 & 5 & 2 & 20 \\
\hline
\end{tabular}

greater at Kazmah compared to Doha, greater at night compared to daylight, and greater on a rising tide compared to a falling tide.

Total biomass (B) was much greater on rising tides than on falling tides at both locations ( $p<0.001$ ). The significant L-D interaction (Table 7 ) indicates that the diel effect was different at the 2 locations. This was investigated by comparing the means of day and night at Doha and Kazmah in each of rising and falling tides. For rising tides biomass was greater at Kazmah than at Doha during both night and day (both $p<0.001$ ). For rising tides biomass was greater at night compared to 
Table 6. F-values and levels of significance for 2-way and 3 way ANOVA's of the spring trawls and seines. $N$ : mean numbers expressed as $\log (x+1)$; $B$ : mean biomass expressed as $\log (x+1)$; L: location; $\mathrm{D}$ : diel period; $\mathrm{T}$. tidal condition; L1 Doha: L2: Kazmah

\begin{tabular}{|c|c|c|c|c|c|}
\hline \multirow{2}{*}{$\begin{array}{l}\text { Source of } \\
\text { variation }\end{array}$} & \multirow[t]{2}{*}{$\mathrm{df}$} & \multicolumn{2}{|c|}{ Trawls } & \multicolumn{2}{|c|}{ Seines } \\
\hline & & $\mathrm{N}$ & B & $N$ & $B$ \\
\hline $\mathrm{L} \times \mathrm{D} \times \mathrm{T}$ & 1 & 2.75 & 0.20 & & 3.35 \\
\hline $\mathrm{D} \times \mathrm{T}$ & 1 & $8.00^{\cdots}$ & 1.65 & & $6.76^{*}$ \\
\hline $\mathrm{L} \times \mathrm{T}$ & 1 & 1.16 & 0.53 & & $12.07^{*} \cdot$ \\
\hline $\mathrm{L} \times \mathrm{D}$ & 1 & 0.09 & 0.28 & & 0.98 \\
\hline L & 1 & $7.20^{\circ}$ & $20.20^{\cdots}$ & & - \\
\hline $\mathrm{D}$ & 1 & - & $6.36^{\circ}$ & & - \\
\hline & 1 & - & 0.72 & & - \\
\hline Residual & 40 & & & & \\
\hline $\begin{array}{l}\text { Seines, } \mathbf{N} \\
\text { Source of } \\
\text { variation }\end{array}$ & df & L1 & L2 & & \\
\hline $\mathrm{D} \times \mathrm{T}$ & 1 & $5.28^{\circ}$ & 0.03 & & \\
\hline D & 1 & - & 0.31 & & \\
\hline $\mathrm{T}$ & 1 & - & 1.90 & & \\
\hline Residual & 20 & & & & \\
\hline \multicolumn{6}{|c|}{$\cdot p<0.05 ; \cdot \cdots p<0.01 ; \cdots p<0.001$} \\
\hline
\end{tabular}
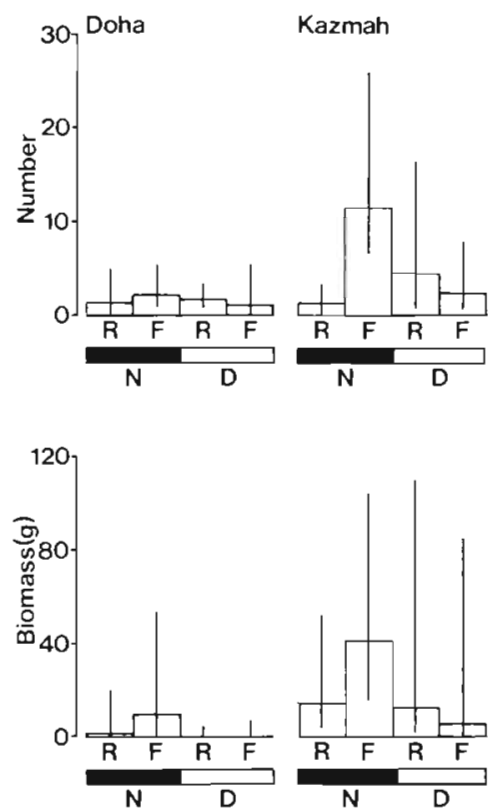

Fig. 2. Spring trawls. Geometric means and $95 \%$ confidence limits of total numbers and total biomass as wet weight at Doha and Kazmah. R: rising tide; $F$ : falling tide; $N$ : night; D: day

the day at both locations (both $p<0.001$ ). For falling tides biomass was greater at Kazmah that at Doha during both night and day (both $\mathrm{p}<0.001$ ). For falling

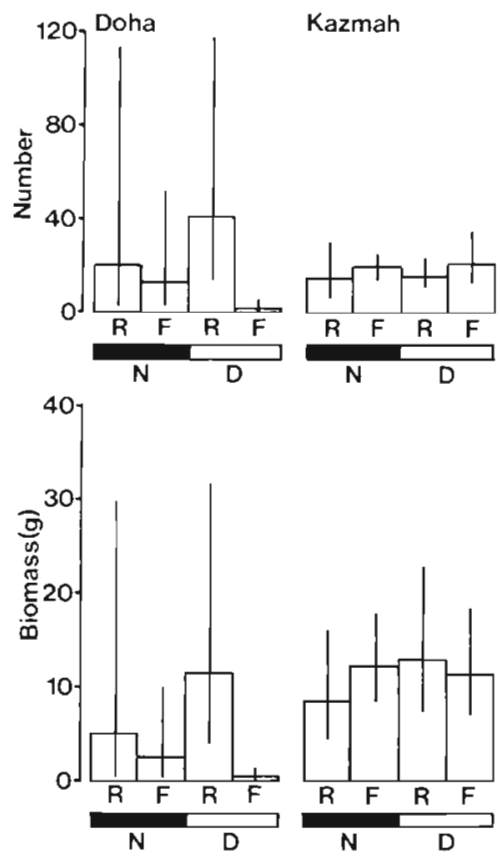

Fig. 3. Spring seines. Geometric means and $95 \%$ confidence limits of total numbers and total biomass as wet weight at Doha and Kazmah. R: rising tide; F: falling tide; N: night; D: day

Table 7 F-values and levels of significance of 3-way ANOVA's of summer trawls and seines. $N$ : mean numbers expressed as $\log (x+1)$; $B$ : mean biomass expressed as

$\log (x+1)$; L: location; $D$ : diel period; $T$. tidal condition

\begin{tabular}{|c|c|c|c|c|c|}
\hline \multirow{2}{*}{$\begin{array}{l}\text { Source of } \\
\text { variation }\end{array}$} & \multirow[t]{2}{*}{$\mathrm{df}$} & \multicolumn{2}{|c|}{ Trawls } & \multicolumn{2}{|c|}{ Seines } \\
\hline & & $N$ & B & $N$ & $B$ \\
\hline $\mathrm{L} \times \mathrm{D} \times \mathrm{T}$ & 1 & 3.9 & 0.78 & 1.60 & 0.09 \\
\hline $\mathrm{D} \times \mathrm{T}$ & 1 & $6.59^{*}$ & 1.77 & 0.81 & 0.24 \\
\hline $\mathrm{L} \times \mathrm{T}$ & 1 & 0.89 & 1.92 & 0.04 & 0.01 \\
\hline $\mathrm{L} \times \mathrm{D}$ & 1 & 0.05 & 0.27 & 1.71 & $5.42^{\circ}$ \\
\hline L & 1 & $6.30^{\circ}$ & 0.001 & $74.6 \cdots$ & - \\
\hline $\mathrm{D}$ & 1 & - & $18.39^{\circ} \cdots$ & $99.35^{\cdots}$ & - \\
\hline $\mathrm{T}$ & 1 & - & 0.27 & $22.47^{\cdots}$ & $14.90^{\circ} \cdots$ \\
\hline Residual & 40 & & & & \\
\hline$\cdot p<0.05$ & . & .001 & & & \\
\hline
\end{tabular}

tides biomass was greater at night than in the day at both locations (both $\mathrm{p}<0.001$ ).

\section{Second sampling programme}

Total numbers ( $N$ ) from the second sampling programme, carried out in Sulaibikhat Bay, which examined C, D, and T, produced only a highly significant tidal effect with much greater catches on rising tides compared to falling tides (Table 8, Fig. 6).

Total biomass (B) was much greater on rising tides 


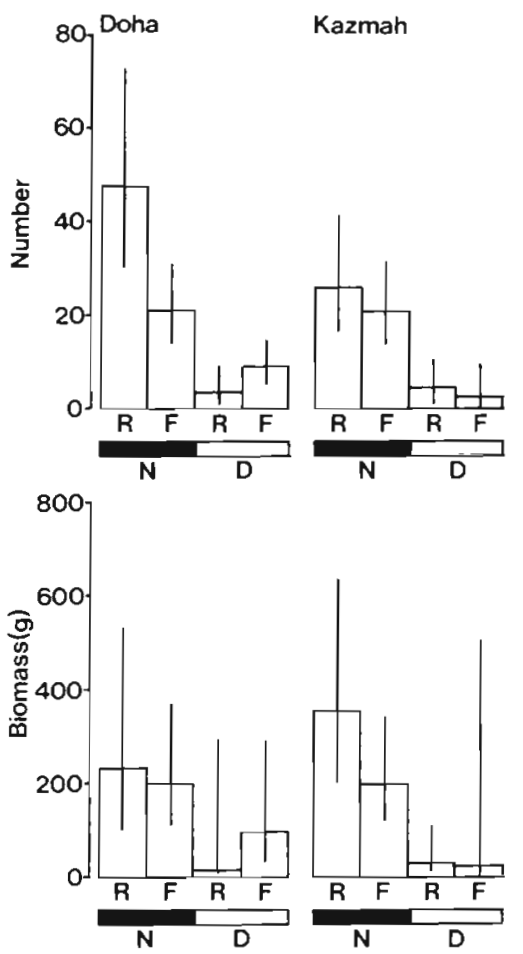

Fig. 4. Summer trawls. Geometric means and $95 \%$ confidence limits of total numbers and total biomass as wet weight at Doha and Kazmah. R: rising tide; F: falling tide; N: night; D: day
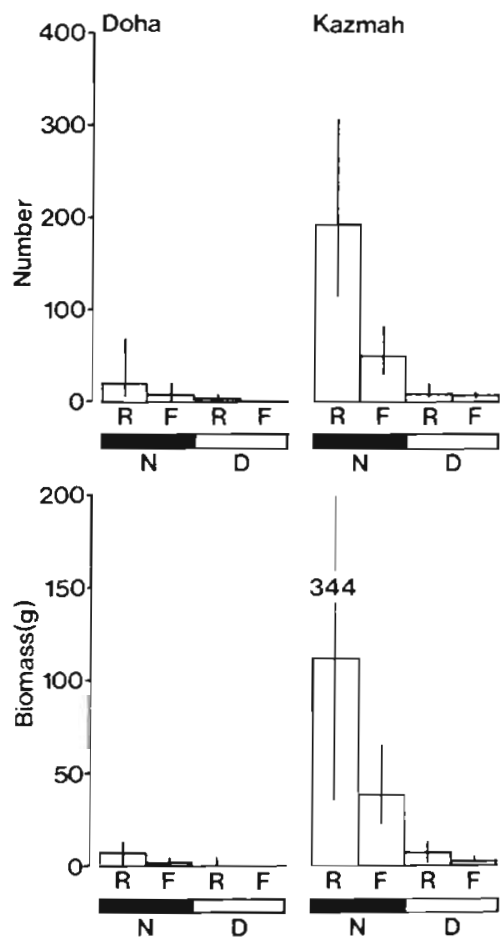

Fig. 5. Summer seines. Geometric means and $95 \%$ confidence limits of total numbers and total biomass as wet weight at Doha and Kazmah. R: rising tide; F: falling tide $e_{i}$ : night; D: day
Table 8. F-values and levels of significance for the 3-way ANOVA of turbidity seines. $N$ : mean numbers expressed as $\log (\mathrm{x}+1)$; $\mathrm{B}$ : mean biomass expressed as $\log (\mathrm{x}+1)$; $\mathrm{C}$ : water clarity; $\mathrm{D}$ : diel period; $\mathrm{T}$ : tidal condition

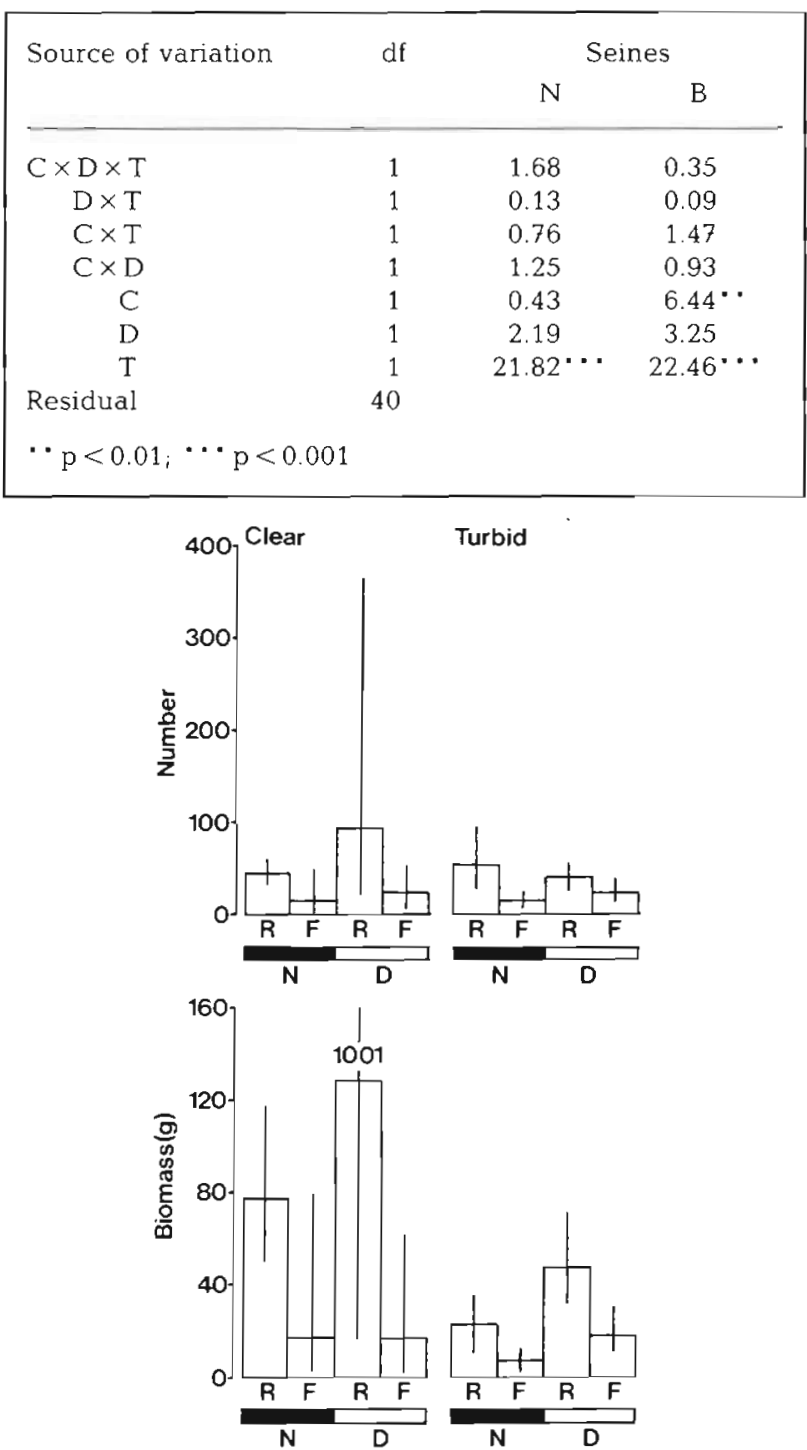

Fig. 6. Sulaibikhat Bay seines. Geometric means and $95 \%$ confidence limits of total numbers and total biomass as wet weight in the clear water and turbid water. R: rising tide;

F: falling tide; $N$ : night; $D$ : day

than on falling tides ( $p<0.001)$, biomass was greater in clear water compared to turbid water $(p<0.01)$ and there was no difference in biomass at night compared to daylight (Table 8).

\section{DISCUSSION}

There were marked diel differences in distribution of the fish assemblage over a $24 \mathrm{~h}$ period between spring and summer. This seasonal difference was shown in 
the monthly trawl catches over a 2 yr period from Sulaibikhat Bay, with largest catches of the year in March and April (Wright 1989a). The high catches were due to Liza carinata and Pomadasys stridens in 1986-1987 (Wright 1988b). In contrast our spring catches were low, the seines being dominated by Liza carinata and the trawls by Leiognathus decorus. The summer seine catches were still dominated by Liza carinata and the trawls by Thryssa hamiltonii.

In general, significant location effects were caused by either the presence of different species or a marked difference in the catches of individual species. Significant diel effects were caused by the presence of different species at night compared to the day, combined with higher catch rates at night. Significant tidal effects were caused by different catch rates of individual species. The observed location effects might be expected when comparing a sand with a mud environment.

The location effect in the spring trawls was due to marked differences in species distributions (Table 1). The catches at Kazmah were dominated by Leiognathus decorus, captured only at Kazmah, while at Doha catches were dominated by Diplodus sargus kotschyi. captured only there. The location effect in the spring seine catches reflects a marked difference in the distribution of Liza carinata which dominated the fish assemblage at both locations (Table 2). At Doha this species was captured either in small shoals or in very low numbers on rising tides both night and day. This is reflected in the large $95 \%$ confidence limits for those tides. At Kazmah this species was more evenly distributed as shown by the small $95 \%$ confidence limits. The location effect in the summer trawl catches is reflected in the distribution of species so that at Doha Terapon puta, Sillago sp., Acanthopagrus latus and Ctenogobius criniger were abundant, while at Kazmah Thryssa hamiltonii and $T$. puta were abundant (Table 3 ). The summer seines show a very clear location effect which is reflected in the distribution of $L$. carinata which was almost absent at Doha but very abundant at Kazmah. Apharius dispar was very abundant at Doha but absent at Kazmah (Table 4).

Other workers have also found marked tidal effects. These effects may be inconsistent (Clark 1974). In some environments no tidal effect was observed for mean numbers or biomass although individual species showed a salinity-related tidal effect (Quinn \& Kojis 1987). Salinity-related tidal effects have been reported by other authors (Robin \& Marchand 1986). Movements by juveniles into drainage channels during low tide as a mechanism to avoid stranding has been reported by several workers (Shenker \& Dean 1979, van der Veer \& Bergman 1986, Wright 1986). Feeding migrations into tidal creeks and tidal pools has been reported (Reis \& Dean 1981, Crabtree \& Dean 1982). Fish assemblage movements have been attributed to tidal related antistranding movements and diel feeding movements (Sogard et al. 1989). Tidally related movements on sandy shores have been extensively reviewed by Gibson (1982) and are considered to be primarily feeding migrations and secondarily a means of avoiding predation.

For trawl catches in the spring there was a significant location effect partially explained by differing species distribution. Diel and tidal effects were not clear at Doha because of low catches. The observed tidal effect at Kazmah was reflected in the distribution of Leiognathus decorus which may be more abundant in shallower water on the rising tide at night than on the rising tide during the day. On a sandy beach in Scotland, young Pleuronectes platessa exhibit a similar asymmetrical migration being found in greater numbers in shallower water during high tide in the night than in the day (Gibson 1973). Feeding in P. platessa takes place mostly during the day and the observed movement into shallower 'water at night is related to the movement of plaice predators into relatively shallower water at night (Edwards \& Steele 1968). In the western Wadden Sea, 0-group plaice show an asymmetrical tidal migration so that fish leave the intertidal earlier in the night compared to the day during the summer to avoid comparatively unfavourable temperature and oxygen conditions (van der Veer \& Bergman 1986). The Wadden Sea is characterised by a depth of 2 to $8 \mathrm{~cm}$ of water on the flats during low tide so that, during the summer, high temperatures may result causing the exodus of plaice during low tide (Berghahn 1986, van der Veer \& Bergman 1986).

The beach seine catches during the spring showed a pronounced location effect although the assemblages at both locations were dominated by Liza carinata. At Doha, catches were greater on the rising tide compared to the falling tide during both night and day, but only significantly so during the day. At Kazmah there was no difference between rising and falling tides. This difference in behaviour of a single species reflects the shore types and water condition. Doha is a sandy shore characterised by water of low turbidity, whilst Kazmah is a muddy shore with consistently turbid water.

The higher catches on the rising tides at Doha compared to the falling tides were probably related to feeding activity. On soft sediment shores, feeding usually has a tidal rhythm but the pattern of feeding is variable (Gibson 1982). For Pomatoschistus minutus feeding is considered to take place only on the rising tide irrespective of day or night (Healey 1971). In a study of several species of Mugilidae some species fed predominantly during the day whilst others fed only during daylight (Blaber 1976). Feeding migrations of Mugilidae have been shown to be dependent on tidal 
movements of food (Romer \& McLachlan 1986). Mugilidae have also been shown to make movements independent of the tide (de Silva \& de Silva 1979). During this study Liza carinata appeared to be feeding in both night and day in which case the highest catches would be expected at the edge of the rising tide. Food accumulated during emersion would become available to the fish as the tide advanced irrespective of diel period. On falling tides the fish would abandon the edge of the tide because it would no longer be relatively rich in food. Combined with this feed-dependent distribution would be the effect of predator avoidance.

Liza carinata was present in shoals on the rising tides during the night and day suggesting that feeding takes place at the edge of the tide and also that there is predator pressure encouraging the formation of shoals. Shoals of pelagic fish usually disperse at night and this has been attributed to 4 effects: insufficient light levels for fish to maintain visual contact; reduced predation pressure at night; offshore movement for spawning during the night; and feeding on nocturnally active prey (Allen \& DeMartini 1983). Of these effects, offshore spawning can be ignored as these fish are juveniles, and feeding on nocturnally active prey is also irrelevant as this species is a detritivore (Wright 1988a).

At Kazmah the spring beach seine rising tide catches were no different from falling tides, suggesting that there was no difference in either food availability or predation pressure between the tides. The typically turbid waters prevent the formation of shoals and may also provide abundant food. Turbidity is considered to be of dual benefit to juvenile fish providing both cover from predators and, by association, a good food supply (Cyrus \& Blaber 1987b). At Kazmah, Liza carinata was more evenly distributed as it was unable to maintain shoals and did not have to compete for food at the edge of the rising tide. In Sulaibikhat Bay the diet of $L$. carinata has been shown to consist mainly of fine grey amorphous detritus containing no sediment particles (Wright 1988a). This suggests that these fish were feeding by skimming the air-water interface. L. carinata was commonly observed in slightly deeper water to be skim-feeding and this may be the preferred method of feeding at Kazmah compared to the more commonly accepted benthic feeding habits of Mugilidae observed at Doha (see Romer \& McLachlan 1986).

The second sampling programme examined the role of turbidity in more detail. Catches during this programme were dominated by Liza carinata and Liza sp. L. carinata showed a tidal movement with greater catches on rising tides. Any diel effect was obscured by the capture of several large shoals interspersed with poor catches on the rising tide during the day in clear water. This resulted in a high mean catch but with very large $95 \%$ confidence limits (Fig. 6). These shoals were not present on the rising tide during the day in turbid water. Liza sp. catches were variable and did not suggest a tidal or diel effect although considerably more were captured in turbid water than calm water. This latter observation may be a result of the first recruitment of these fish to the shore, typically at $20 \mathrm{~mm}$ total length, after the first sampling date in this programme. There was no difference in catches between clear and turbid water but there was a marked difference in the distribution of $L$. carinata between the 2 water conditions. Under clear water conditions, shoals formed only on the rising tide during daylight. This lack of shoals at night, at odds with the observed shoal formation at night during spring, may be due to several factors. When compared to conditions at Doha in spring, the water may have been relatively less clear so that $L$. carinata was unable to form shoals at night. The second sampling programme was carried out 2 mo after the spring programme, during which time the fish had grown. This size increase may have reduced predation. pressure sufficiently so that shoal formation was no longer necessary at night. Whilst no shoals were caught in turbid conditions there was a marked tidal effect suggesting that even under turbid conditions there was still some advantage in congregating at the tide edge on a rising tide.

The summer trawls showed a significant location effect attributable to the presence of different species at the 2 locations. Night catches were greater than day catches at both locations. Similar results were found in Sulaibikhat Bay (Wright 1989a). The tidal effect was significant at Doha with higher catches on rising tides suggesting a feeding migration into shallow water, but at Kazmah no movement was apparent and this may be due to the more turbid conditions there.

For the summer seines there were clear location, diel and tidal effects. The marked location differences may be due to the fact that the shores were dominated by different species. The dominant species at Doha was Aphanius dispar, captured exclusively there, and at Kazmah Liza carinata.

The higher night catches at both locations may be due to several effects. During the day fish may be avoiding diurnally active piscivorous birds and would tend to be found in deeper water. Deeper water during the day may provide energetic advantages such that metabolic rate will be reduced in the cooler water. At night the fish concentrate in shallow water to avoid predatory fish that migrate nocturnally toward the shore (Wright 1989a).

The observed highly significant tidal effect in the summer seines is due to the feeding migration at the edge of the rising tide followed by dispersal on the falling tide and is not due to any tidal change in the species constituting the assemblage. 
In summary there was a pronounced seasonal effect as well as a marked location effect on the constituent species of the assemblage. Liza carinata showed a marked change in behaviour as a result of growth so that very small juveniles formed shoals at night whereas larger juveniles did not. Diel effects were not clear in the spring, but were pronounced in the summer. In the spring seines tidal effects were very pronounced in the clear waters at Doha but lacking in the turbid waters of Kazmah. In the spring trawls at Kazmah, Leiognathus decorus made an asymmetrical tidal migration. In the summer, tidal migrations were very clear in the seines but not in the trawls.

Acknowledgements. This work was supported by Kuwait University grant SZ027. Dr D. Young helped with the use of GLIM. We thank Mr Tarek Al-Kanani for technical help.

\section{LITERATURE CITED}

Allen, L. G., DeMartini, E. E. (1983). Temporal and spatial pattern of nearshore distribution and abundance of the pelagic fishes off San Onofre-Oceanside, California. Fish. Bull. U.S. 81. 569-586

Baker, R. J., Nelder, J. A. (1978). The GLIM system release 3 manual. Numerical algorithms group, Oxford

Blaber, S. J. M. (1976). The food and feeding ecology of Mugilidae in the St. Lucia lake system. Biol. J. Linn. Soc. 8: 267-277

Blaber, S. J. M., Blaber, T. G. (1980). Factors affecting the distribution of juvenile estuarine and inshore fish. J. Fish Biol. 17: 143-162

Berghahn, R. (1986). Determining abundance, distribution and mortality of $\mathrm{O}$-group plaice (Pleuronectes platessa L.) in the Wadden Sea. J. appl. Ichthyol. 2: 11-22

Clark, S. H. (1974). A study of variation in trawl data collected in the Everglades National Park, Florida. Trans. Am. Fish. Soc. 4: 777-785

Crabtree, R. E., Dean, J. M. (1982). The structure of two South Carolina estuarine tide pool fish assemblages. Estuaries 5: 2-9

Cyrus, D. P., Blaber, S. J. M. (1987a). The influence of turbidity on juvenile fishes in estuaries. Part 1. Field studies at Lake St. Lucia on the southeastern coast of Africa. J. exp. mar Biol. Ecol. 109: 53-70

Cyrus, D. P., Blaber, S. J. M. (1987b). The influence of turbidity on juvenile fishes in estuaries. Part 2. Laboratory studies, comparisons with field data and conclusions. J. exp. mar Biol. Ecol. 109: 71-91

Edwards, R., Steele, J. H. (1968). The ecology of 0-group plaice and common dabs at Lochewe. I. Population and food. J. exp. mar Biol. Ecol. 2: 215-238

Gibson, R. N. (1973). The intertidal movements and distribution of young fish on a sandy beach with special reference to the plaice (Pleuronectes platessa L.). J. exp. mar. Biol. Ecol. 12: 79-102

Gibson, R. N. (1982). Recent studies on the biology of intertidal fishes. Oceanogr. mar Biol. A. Rev. 20: 363-414
Healey, M. C. (1971). The distribution and abundance of sand gobies, Gobius minutus, in the Ythan estuary. J. Zool. Lond. 163: 173-229

Jones, D. A., Clayton, D. A. (1983). The systematics and ecology of crabs belonging to the genera Cleistostoma de Haan and Paracleistostoma de Man on Kuwait mudflats. Crustaceana 45: 183-199

Jones, F. R. H., Arnold, G. P., Walker, M. G., Scholes, P. (1979). Selective tidal stream transport and the migration of plaice in the southern North Sea. J. Cons. int. Explor. Mer 38: 331-337

Lenanton, R. C. J. (1982). Alternative non-estuarine nursery habitats for some commercially and recreationally important fish species of South-Western Australia. Aust. J. mar. Freshwat. Res. 33: 881-900

Quinn, N. J., Kojis, B. L. (1987). The influence of diel cycle, tidal direction and trawl alignment on beam trawl catches in an equatorial estuary. Environ. Biol. Fish. 19: 297-308

Reis, R. R., Dean, J. M. (1981). Temporal variation in the utilization of an intertidal creek by the Bay Anchovy (Anchoa mitchilli). Estuaries 4: 16-23

Robin, J. P., Marchand, J. (1986). Preliminary observations on the feeding activity of fishes during tidal and diel cycles in the Loire Estuary The Bib Trisopterus luscus L. 1758. P.S.Z.N.I: Mar. Ecol. 7. 181-189

Romer, G. S., McLachlan, A. (1986). Mullet grazing on surf diatom accumulations. J. Fish Biol. 28: 93-104

Ross, S. T., Michael, R. H., Jr, Ruple, D. L. (1987). Seasonal and diel variation in the standing crop of fishes and macroinvertebrates from a Gulf of Mexico surf zone. Estuar. coast. Shelf Sci. 25: 391-412

Shenker, J., Dean, J. M. (1979). The utilization of an intertidal salt marsh creek by larval and juvenile fishes: abundance, diversity and temporal variations. Estuaries 2: 154-163

Silva, S. S. de, Silva, E. I. L. de (1979). Biology of young grey mullet, Mugil cephalus L., populations in a coastal lagoon in Sri Lanka. J. Fish Biol. 15:9-20

Sogard, S. M., Powell, G. V N., Holmquist, J. G. (1989) Utilization by fishes of shallow, seagrass-covered banks in Florida Bay: 2. Diel and tidal patterns. Environ. Biol. Fish. 24: $81-92$

Veer, H. W van der, Bergman, M. J. N. (1986). Development of tidally related behaviour of a newly settled 0 -group plaice (Pleuronectes platessa) population in the western Wadden Sea. Mar Ecol. Prog. Ser 31: 121-129

Walker, M. G., Jones, F. R. H., Arnold, G. P. (1979). The movements of plaice (Pleuronectes platessa L.) tracked in the open sea. Cont. int. Explor. Mer 38: 58-86

Wright, J. M. (1986). The ecology of fish occurring in shallow water creeks of a Nigerian mangrove swamp. J. Fish Biol. 29: 431-441

Wright, J. M. (1988a). Recruitment patterns and trophic relationships of fish in Sulaibikhat Bay., Kuwait. J. Fish Biol. 33: 671-687

Wright, J. M. (1988b). Seasonal and spatial differences in the fish assemblage of the non-estuarine Sulaibikhat Bay., Kuwait. Mar. Biol. 100: 13-20

Wright, J. M (1989a). Diel variation and seasonal consistency in the fish assemblage of the non-estuarine Sulaibikhat Bay., Kuwait. Mar. Biol. 102: 135-142

Wright, J. M (1989b). Detached chlorophytes as nursery areas for fish in Sulaibikhat Bay, Kuwait, Estuar. coast. Shelf Sci. 28: $185-193$

Manuscript first received: December 4, 1989

Revised version accepted: May 23, 1990 